\title{
Metabolic hallmarks of cancer cells as targets for integrative therapies
}

\author{
John Ionescu* and Alexandru Tudor Constantinescu \\ Spezialklinik Neukirchen, Krankenhausstr 9, 93453 Neukirchen, Germany
}

\section{Introduction}

In 2018, 18.1 million people around the world had cancer, and 9.6 million died from the disease. By 2040, those figures will nearly double [1]. An increasing body of evidence is suggesting that the reason for this evolution is twofold: on the one hand, environmental, nutritional and lifestyle factors play an important role in the disease etiology, while, on the other hand, most current therapies are killing tumor and healthy cells alike, instead of specifically targeting common metabolic hallmarks of cancer cells. Among the latter we could mention: the significant changes of $\mathrm{pH}$ and redox potential inside and outside the tumor cells, their energy generating pathways relying on aerobic glycolysis, glutaminolysis or fatty acid oxidation, the activation of the NADPH:quinone-oxidoreductases, as well as the high accumulation of transitional metals and organic pollutants in the tumor tissue accompanied by inactivation of several antioxidative and detox systems. This review concentrates on the metabolic and toxicologic markers of cancer cells and proposes a new integrative approach in this respect.

\section{Role of metal accumulation in cancer etiology and therapy}

In recent decades, the presence of transition metals such as iron, copper, nickel or chromium in connection with the production of free radicals through Fenton/Haber-Weiss reactions, autoxidation of ascorbate, peroxidation processes of fatty acids and formation of DNA strand breaks has been reported [2,3]. In order to explore the connection between environment and cancer growth in humans, we assessed the accumulation of transitional metals and aluminum in healthy and breast cancer biopsies. Our Atomic Absorption Spectrometry measurements showed for the first time a highly significant accumulation of iron, nickel, chrome, zinc, cadmium, mercury, lead and aluminum in breast tumor biopsies, when compared to the control biopsies [4,5] (Figure 1). Subsequent independent studies have confirmed our findings, reporting significantly increased concentrations of iron, aluminium, chromium, nickel and zinc when compared to either healthy surrounding tissue or samples from healthy persons undergoing mammoplasty [6-9].

Proliferating cells have an increased iron requirement, which is fulfilled by overexpression of transferrin receptors (TfR1) on the cell surface. Normal lymphocytes increase the density of TfR 1 by 50 times after stimulation with mitogenic factors and transformed lymphoid cells even have 1,000 times the number of TfR1 [10,11]. In accordance with our findings $[4,12]$, clinical research results show a significantly higher transferrin receptor density and ferritin accumulation in breast cancer tissue [13]. Furthermore, iron deficiency in the culture medium leads to apoptosis of cancer cells [14]. The overexpression of zinc transport proteins (ZIP4, ZIP10, LIV-1) is also well documented in cancer cells [15-17].

Once absorbed in the cell, iron is used on the one hand for the synthesis of iron-containing enzymes, on the other hand is stored as ferritin complex.

The high intracellular concentration of transitional metals leads to high ROS production via Haber-Weiss and Fenton reactions [4] (Figure 2), and may be responsible for the considerable genetic variability/ heterogeneity of tumor cells, even within the same tumor, among other exogenous ROS sources [18-20].

In view of these facts, the widespread clinical prescription of iron and zinc preparations for cancer patients appears to be rather counterproductive, as the malignant cells are preferentially supplied with these metals. Actually, one should try to counteract the iron excess. Indeed, chelating iron and simultaneously inhibiting the formation of the Tf-TfR 1 complex by means of monoclonal antibodies were both able to inhibit tumor growth in a mouse model, much more efficiently than any single agent [21]. Furthermore, clinical studies have also shown the benefits of iron chelators as anti-cancer therapy in neuroblastoma and leukemia cases [22-25].

$\mathrm{Ni}, \mathrm{Cr}$ and $\mathrm{Cd}$ have been identified as mutagens and carcinogens due to their ability to inhibit the repair of damaged DNA. Besides, they are also able to increase the mutagenicity and carcinogenicity of directly acting genotoxic substances [26]. The carcinogenic effects of $\mathrm{Ni}$, directly or in combination with organic compounds, have been described in the literature $[27,28]$ and slightly elevated concentrations of Fe and Ni have been found in malignant human prostate tissue [29]. Inhalation of certain forms of hexavalent chromium causes lung cancer and, at cellular level, chromium exposure can inhibit apoptosis or induce neoplastic changes [30]. Occupational cadmium exposure can cause lung cancer and high cadmium concentrations have been found in proliferative prostate lesions [31].

${ }^{\star}$ Correspondence to: John Ionescu, Spezialklinik Neukirchen, Krankenhausstr 9, 93453 Neukirchen, Germany, E-mail: info@spezialklinik-neukirchen.de

Key words: cancer, tumor metabolism, heavy metals, free radicals, oxidosis/ redosis, acidosis/alkalosis, aerobic glycolysis, $\mathrm{Na}+\mathrm{H}+$ antiporter systems, carbonic anhydrases, hyperthermia, vitamin $\mathrm{C}$, Na-bicarbonate, polyphenols, ketogenic diet, glycemic index, glycolysis inhibitors, integrative cancer therapy, neoplasm, neoplasms/metabolism, glycolysis/drug effects, heavy metals, hydrogen-ion concentration, ascorbic acid, polyphenols, ketogenic diet, complementary therapies

Received: April 28, 2020; Accepted: May 11, 2020; Published: May 14, 2020 
Iron content of 20 breast cancer and 8 control human biopsies.
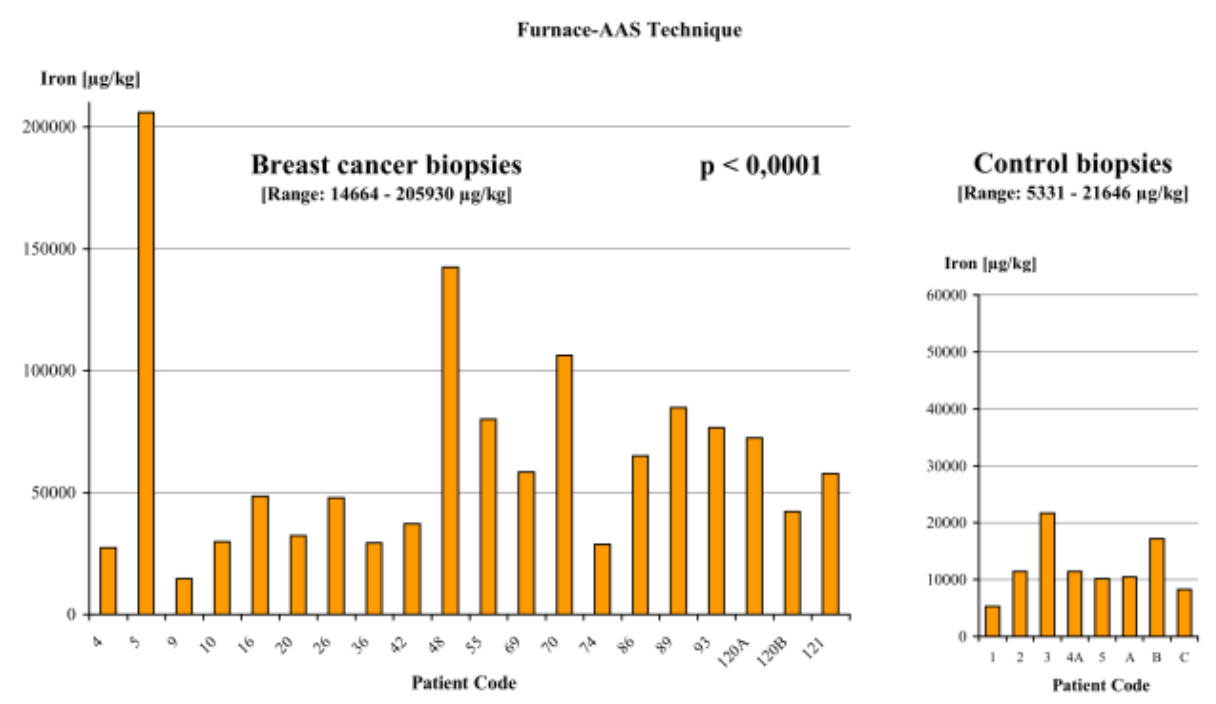

Nickel content of 20 breast cancer and 8 control human biopsies.

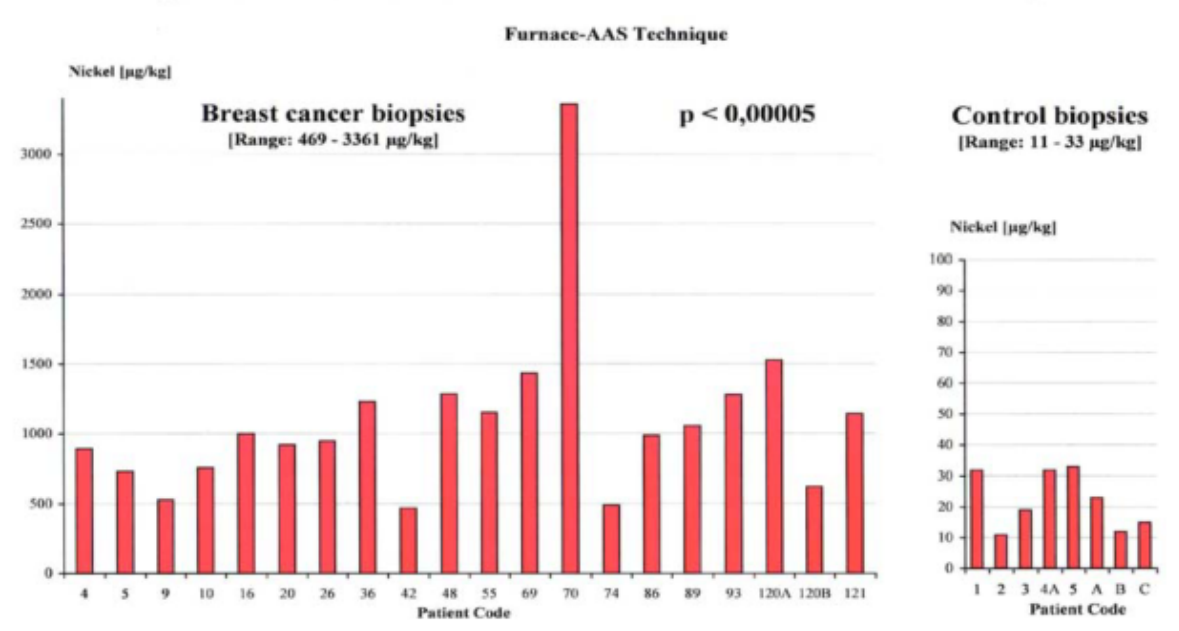

Zinc content of 20 breast cancer and 8 control human biopsies.

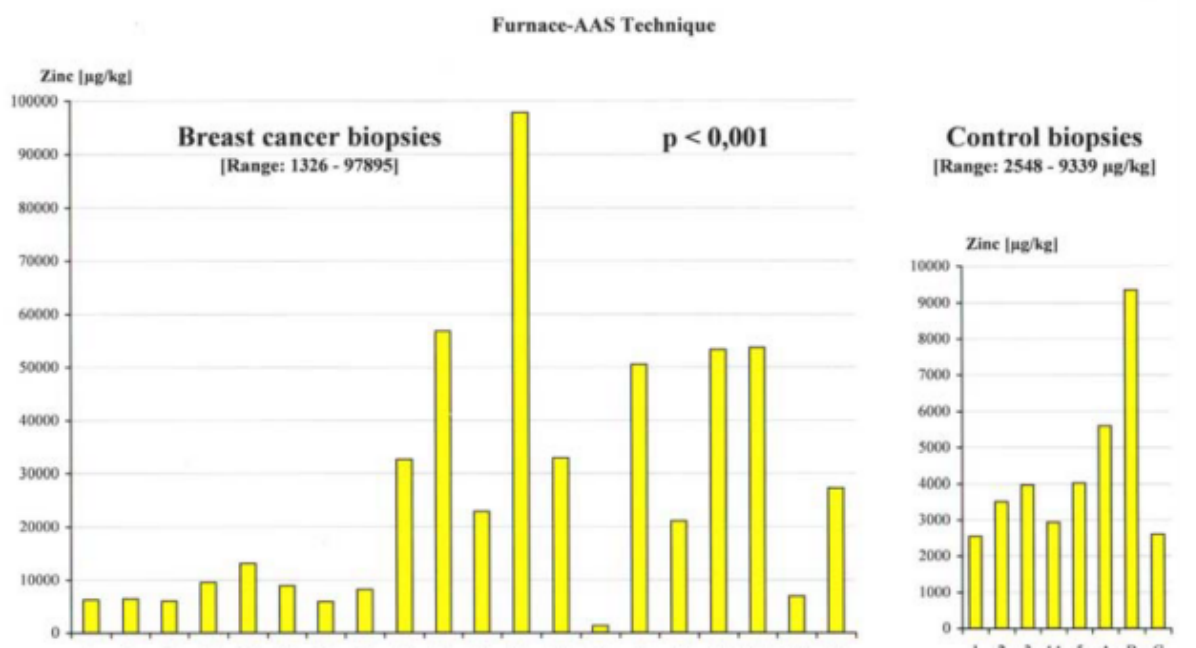

Figure 1. The iron, nickel and zinc content in the 20 breast cancer biopsies is up to $10 \mathrm{X}, 100 \mathrm{X}$ and $25 \mathrm{X}$ higher than in the control biopsies [10] 


$$
\begin{aligned}
& 2 \mathrm{O}_{2}^{-}+2 \mathrm{H}^{+} \stackrel{\mathrm{SOD}}{\longrightarrow} \mathrm{O}_{2}+\mathrm{H}_{2} \mathrm{O}_{2} \\
& \mathrm{H}_{2} \mathrm{O}_{2}+\mathrm{O}_{2}^{-} \underset{\begin{array}{c}
\text { Haber-Weiss } \\
\text { Reaktion }
\end{array}}{\stackrel{\mathrm{Fe}^{3+}, \mathrm{Cu}^{2+}}{\longrightarrow}} \mathrm{HO}^{*}+\mathrm{HO}^{-}+\mathrm{O}_{2} \\
& \mathrm{Fe}^{2+}+\mathrm{H}_{2} \mathrm{O}_{2} \underset{\text { Fenton Reaktion }}{\longrightarrow} \mathrm{Fe}^{3+}+\mathrm{HO}^{*}+\mathrm{HO}^{-}
\end{aligned}
$$

Figure 2. The production of hydroxyl radicals in H2O2- and metal- dependant Fenton and Haber-Weiss reactions

$\mathrm{Ni}, \mathrm{Cd}$ and $\mathrm{Cr}$ activate the estrogen receptors in the absence of estradiol [32-34] thus acting as "endocrine disruptors" or "metalloestrogens". As a consequence, exposure to these metals can increase the breast cancer risk [35] and stimulate growth of ER+ breast cancer cells [32].

Metalloestrogens also trigger changes of the estrogen binding sites of genes in the cell nucleus. In mammary gland cells, this leads to an increase in cell division and more errors in DNA amplification, augmenting the risk of cancer [32].

Interestingly, it has been shown that zinc and overexpression of its transporters mediate and accelerate tumor growth as a necessary trace element $[15,17]$, while zinc deficiency in mice and rats proved to inhibit tumor growth [36-38].

Due to the increasingly broad contact with aluminum compounds, a growing amount of data regarding the involvement of this light metal in tumor development and growth through its mitochondrialdamaging and estrogen-like effects is accumulating [39-41].

The etiology of most human breast tumors is still controversial. We have argued that environmental pollutants that cause oxidative stress and lipid peroxidation can additionally act as endocrine disruptors in the development of breast cancer [35,42].

Therefore, chronic toxic exposure to transition metals and / or organic pollutants, combined with genetic polymorphisms of detoxification phase I+II enzymes and overexpression of transport proteins or their receptors, may be responsible for this phenomenon [43].

\section{Redox state and $\mathrm{pH}$ in malignant tumors}

The redox and $\mathrm{pH}$ shifts define electron or proton transfer reactions in biological or chemical systems. They are correlated according to the rule: the lower the $\mathrm{pH}$, the higher the redox potential (Eh), and the higher the $\mathrm{pH}$, the lower the redox potential. Shapiro [44] defines redosis as the accumulation of non-volatile reductive equivalents (such as glutathione, NADH, cysteine, glucose), as opposed to the accumulation of oxidative substances $\left(\mathrm{O}_{2}, \mathrm{O}_{3}\right.$, halogens, metals in oxidized form, environmental pollutants, etc.), which is defined as oxidosis. The measurement of the redox potentials in blood, plasma or tissue (Eh in $\mathrm{mV}$ ) reflects the sum of all redox pairs in the sample, whereby usually the ratio between the reduced and oxidized glutathione (GSH / GSSG) and $\mathrm{pO}_{2}$ are decisive for the cellular redox status [45]. The Eh correlates with the biological status of normal cells: $-220 \mathrm{mV}$ (redosis / proliferation), -200 $\mathrm{mV}$ (differentiation), -170 $\mathrm{mV}$ (oxidosis / apoptosis) [46], while proliferating cancer cells exhibit a permanent redosis $(-220 \mathrm{mV}$ or lower) with an increased accumulation of reduced glutathione, NADH, NADPH, cysteine, or glucose via GLUT transporters [47-51].

This redosis shift may be due to hypoxic states and / or a significant accumulation of electrophilic organic noxae [52-54] and transitional metals $[4,42,55]$ in degenerated tissues after failure of the corresponding detoxification and antioxidant protection systems (GST, SOD, catalase) [56-61]. In this respect, the increased glutathione synthesis of malignant cells is regarded as an adaptive response and resistance mechanism against various pro-oxidative attacks (accumulation of heavy metals or organotoxins, chemotherapy, radiation, endogenous ROS production) and is associated with their propensity to proliferate $[4,18,43,62-64]$.

\section{Intracellular and extracellular $\mathrm{pH}$ in tumor tissues}

$\mathrm{pH}$ measurements in healthy tissues under normal $\mathrm{pO}_{2}$ values associate temporary growth factor-induced proliferation with an intracellular alkalization and increased aerobic glycolysis [65-67]. In accordance with the existing redosis, proliferating cancer cells exhibit permanent intracellular alkalization ( $\mathrm{pHi} 7.12$ - 7.65) compared to normal cells (pHi 6.99-7.20) [68-70], combined with a strong aerobic glycolysis, which was already described in the 1930's as the Warburg effect [71-73].

The permanent intracellular alkalization of proliferating cancer cells is largely due to an activation of the $\mathrm{Na}+\mathrm{H}+$ antiporter system NHE1 [74,75], the V-ATPase proton pump [76-78] and the MCT lactate transporter, which ensure an uninterrupted discharge of protons $(\mathrm{H}+)$ and lactate in the extracellular space [79].

Hypoxia- and HIF1-caused hyperexpression of membrane-bound and zinc-dependent carbonic anhydrases CA2, CA9 and CA12 have already been demonstrated in many tumors [80-83] and together with anion exchangers such as $\mathrm{Cl}^{-} / \mathrm{HCO}_{3}^{-}$(AE1) are involved in disease progression $[84,85]$. Accordingly, there is a pronounced acidic extracellular environment in tumor tissue (pHe 6.2 - 6.9) compared to normal tissue (pHe 7.3 - 7.4), which clearly promotes tumor growth and metastasis $[68,86]$ and blocks the activity of immunocompetent cells $[87,88]$.

\section{Activation of aerobic glycolysis (Warburg effect)}

The intracellular $\mathrm{pH}$ increase in malignant cells can activate aerobic glycolysis at normal $\mathrm{pO}_{2}$ concentrations $[69,79,86]$. Activation of the glycolysis enzymes hexokinase (HK), phosphofructokinase (PFK), pyruvate dehydrogenase kinase (PDK1) and the pentose-5-phosphate pathway (via G6PDH and transketolase-TKTL1) leads, on the one hand, to a direct inhibition of OXPHOS in the mitochondria and, on the other hand, via high pyruvate concentrations, to an increase of Hypoxia Inducible Factor (HIF1) [89,90]. The latter plays a key role in the genetic transcription of the glucose transporter (GLUT 1) and the glycolysis enzymes, as well as in the inhibition of pyruvate dehydrogenase (PDH) with reduction of pyruvate conversion to acetyl-CoA and subsequent inhibition of Krebs cycle or oxidative phosphorylation [91,92]. HIF1 also activates carbonic anhydrase CA9 in tumor cells and thus maintains the extracellular acidosis [80-82].

\section{Cancer metabolic hallmarks as therapy targets}

In view of the already mentioned genetic variability of cancer cells within a tumor and the associated resistance to therapy, the basic toxicological and molecular-biological characteristics mentioned above (Figure 3) are of particular importance for new complementary treatment approaches. In vitro and in vivo studies of the last years, as 
well as our own therapy experiences show a significant antiproliferative and pro-apoptotic effect in tumors by means of:

- High-dose vitamin $\mathrm{C}$, which has a strong pro-oxidative effect in the presence of increased cellular metal concentrations via ROS formation [4,10,93]. Accordingly, the increased heavy metal concentration in various tumors can be used for therapeutic approaches with vitamin $\mathrm{C}$ or polyphenols, as previously reported [94-97]. The reduction and mobilization of transition metals from their storage or transport proteins make them extremely reactive for the catalysis of free radical reactions.

- The Fenton and Haber-Weiss reactions described above generate hydroxyl radicals to a high degree, which can lead to lipid peroxidation, interruptions of DNA strands and apoptosis [3,94,98]. The autoxidation of vitamin $\mathrm{C}$ with production of superoxide and hydrogen peroxide in the presence of transition metals such as iron, nickel, chromium or mercury can be clearly detected in human serum using a chemiluminescence method [99]. In an acidic environment $(\mathrm{H}+$ excess in extracellular space) the superoxide radical is converted into $\mathrm{H}_{2} \mathrm{O}_{2}$ and can induce apoptosis/necrosis of tumor cells.

- Due to the highly significant accumulation of heavy metals in tumor tissue, we have described for the first time the above mechanism as an explanation for the pro-oxidative, tumor-specific activity of vitamin C $[4,10,43,93]$. In contrast, healthy, non-metal contaminated cells are antioxidatively protected by vitamin C. Clinical studies and our own experience with pharmacologically active doses of Vitamin C administered i.v. prove that such approaches can lead to dramatic shrinkage of the tumor, an extension of the patient's life and to an increase of their quality of life [5].

- Natural polyphenols generate, in the presence of increased metal concentrations (Figure 4) $[10,97,100]$ or activated NADPH : quinone oxidoreductases, superoxide and semiquinone radicals and thus exhibit a strong pro-oxidative effect. As discussed above, tumors tend to accumulate heavy metals; the activity of the microsomal NADPH : quinone oxidoreductase, has been shown to be strongly increased in various tumor types [101]. Through these two pathways, in situ bioactivation of phenolic and polyphenolic therapeutics occurs in a tumor-selective manner [102,103], leading to a significant production of superoxide, $\mathrm{H}_{2} \mathrm{O}_{2}$ and semiquinone radicals and thus to a selective increase of the redox potential in the tumor [101]. Curcumin combined with classical chemoterapeutics

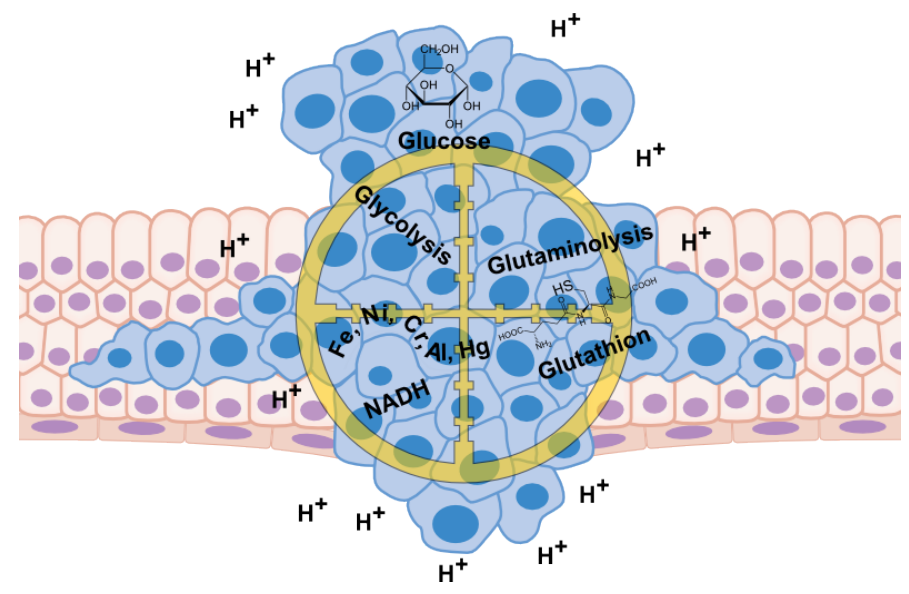

Figure 3. Metabolic targets of integrative oncology such as Cisplatin or Docetaxel led in mouse models of head and neck, respectively ovarian carcinoma to a suppression up to $96 \%$ of the tumor growth $[104,105]$.

- The elimination of intracellular redosis with the help of prooxidative approaches such as hyperthermia [99], short-term fasting (3-5 days) [106,107], ketogenic diet [108-110] and regular physical exercise [111].

- Studies in animal models could show that the association of a ketogenic diet with radiotherapy can lead to a complete remission of the tumor, and that the animals remained tumor-free even 200 days after withdrawal from the ketogenic diet [109]. A specially formulated nutritional formula developed for the treatment of epilepsy (KetoCal) could diminish up to 65\% the growth and vascularization of gliomas implanted in mice and significantly increase their survival rate [139].

- First clincal studies on patients with advanced carcinomas show that a ketogenic diet with an insulin lowering effect can be considered safe and that the concentrations of ketone bodies correlate with the stabilization of the disease or even remission [112].

- The use of basic solutions such as Ringer's lactate or $\mathrm{NaHCO}_{3}$ to buffer the extracellular acidosis with anti-inflammatory and metastasis-inhibiting effects [113-115]. Simply the use of bicarbonate perfusions leads to a selective increase of intratumoral $\mathrm{pH}$ concomitantly with a decrease of new metastases generation, as well as a remarkable improvement of the therapeutic efficiency of Doxorubicin in mouse models [115].

- The usage of proton pump inhibitors from the Omeprazole family $[77,116]$, which were shown in mouse models of B-Cell lymphoma to lead to a significant slowing of the tumor growth [117] and to a significant lowering of the incidence of esophageal adenocarcinoma in patients with Barrett's Esophagus [118]. Also, V-ATPase-Inhibitors such as the macrolid antibiotics Bafilomycin A and Concanamycin A lead to a similar acidification of the tumoral millieu and apoptosis [76,119]. This finding was confirmed in clinical studies: breast cancer patients who received Esomeprazol before the chemotherapy had an almost double progression-free survival compared to the group receiving the standard chemotherapy (10.7 vs 5.8 months) [120].

- The inhibition of the $\mathrm{Na}^{+} / \mathrm{H}^{+}$antiporter (NHE1) for the purpose of intracellular pHi reduction and apoptosis induction via 5-HMA and other amiloride derivatives in leukemia and hepatocarcinoma cells [121-123]

- The inhibition of carbonic anhydrase (CA) via acetazolamide [124], sulphonamides [80,81], coumarins, thiocoumarins or hydroxycinnamic acids $[125,126]$.

- The inhibition of aerobic glycolysis with specific inhibitors of hexokinase (Lonidamine, 2-deoxyglucose, 3-bromo pyruvate), G6PDH (6-aminonicotinamide), the transketolase TKTL1 (oxythiamine), PDK-1 (dichloroacetate), glyceraldehyde phosphate dehydrogenase (chlorohydrin, ornidazole, arsenate) and lactate dehydrogenase A (anti-RNA) or of glucose transporters (GLUT13) via genistein, 5-thioglucose and mannoheptulose (Figure 5) [43,127-130].

- The selection of an appropriate form of nutrition with a low glycemic index not promoting tumor growth.

- Low in sugar, flour products, zinc, iron, nickel, chromium, folic acid, alcohol, glutamine, fat peroxides etc. [5]. 

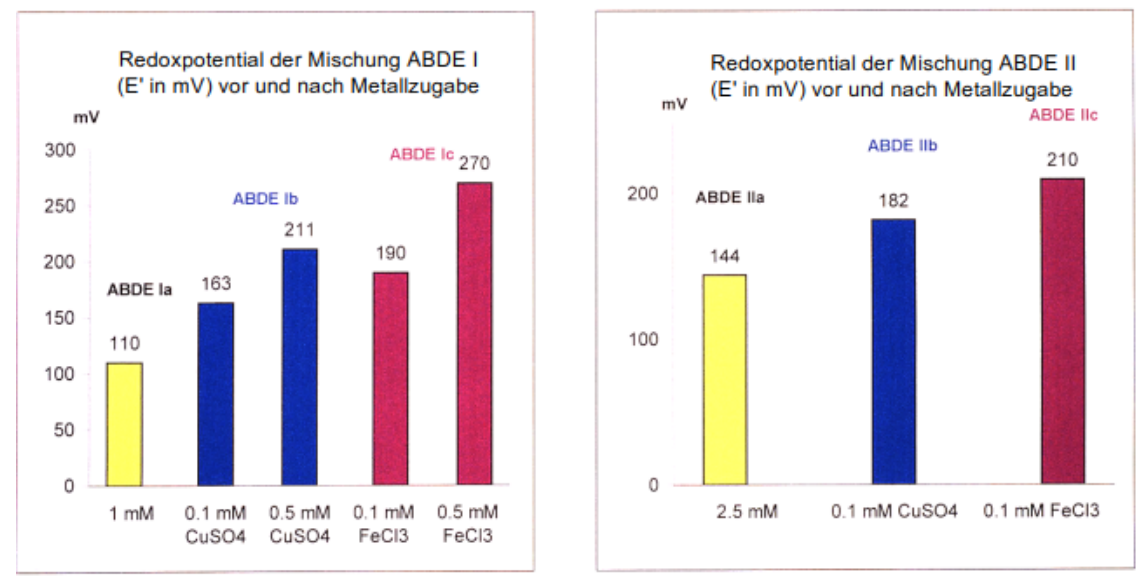

Figure 4. Substituted phenols show a pro-oxidative effect in the presence of $\mathrm{Cu}^{2+}$ or $\mathrm{Fe}^{3+}[10]$

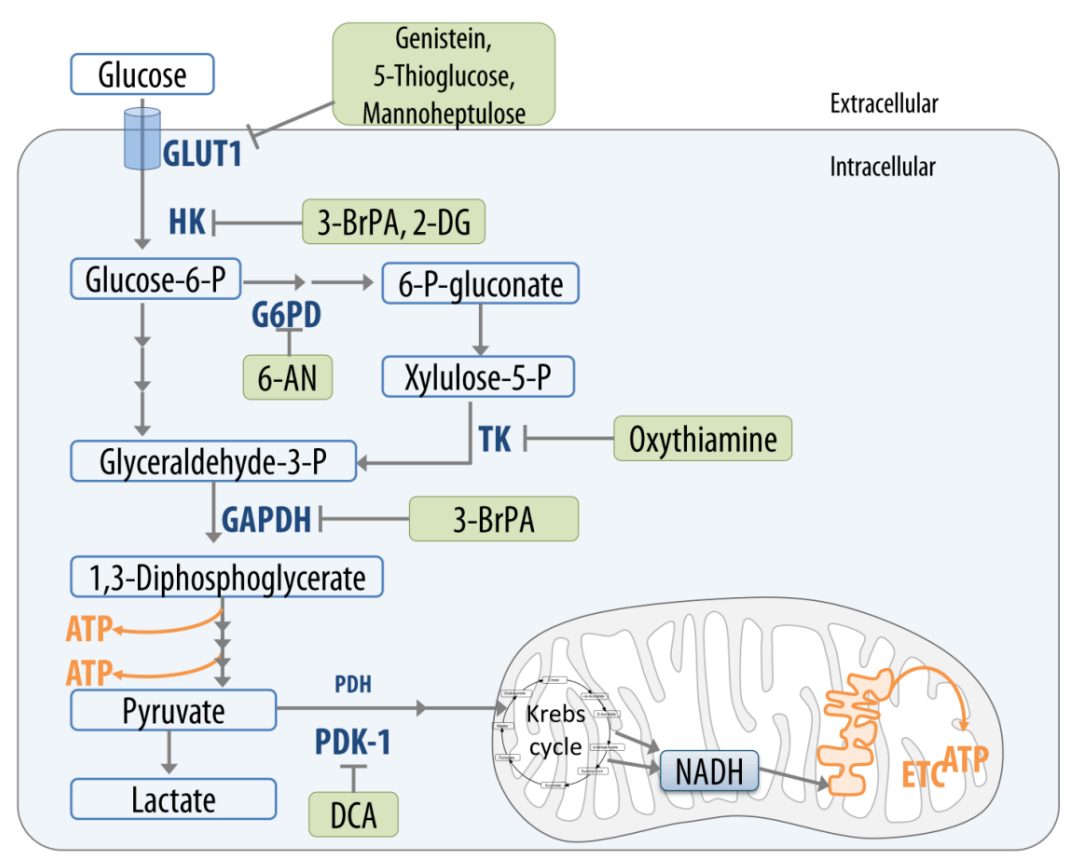

Figure 5. Inhibitors of glycolysis, of pentose-5-phosphat pathways and GLUT1 in an integrative cancer therapy model

- Rich in omega-3 fatty acids, vitamin D3, carotenoids, complex $\mathrm{CHOs,} \mathrm{high-dose} \mathrm{enzyme} \mathrm{preparations,} \mathrm{plant} \mathrm{proteins,} \mathrm{mixtures}$ of selected amino acids, sphingolipids, phytosterols, isoflavonoids, polyphenols, $\mathrm{L}+$ lactic acid and pro-oxidative vegetable and fruit juices etc. [131].

\section{Conclusion}

The causal link between the increasing environmental pollution (diesel exhaust, pesticides, wood preservatives, phthalates, solvents, tobacco smoke, alcohol, heavy metals, preservatives, dyes, etc.) and the continuous raise in cancer incidence is currently well documented. Their accumulation in cancer tissue leads to oxidative stress, followed by DNA mutations and thus to an increase in the intra- and intertumoral genetic variability $[19,132]$. This dynamic heterogeneity is the main cause for resistance to the classic oncologic therapies.

Since the redox, $\mathrm{pH}$ and glycolysis shifts in tumor tissue are regarded as metabolic markers of all cancer cells, they emerge as new therapeutic targets in modern oncology.
The novel treatment approaches mentioned in this paper, per se or in combination with classical oncological therapies, can lead to a considerable increase in life expectancy and life quality. A detailed description of the above strategies, also addressing alternate energygenerating pathways such as glutaminolysis and fatty acid synthesis/ oxidation will be published elsewhere.

\section{Acknowledgments}

We thank Dr. Raluca Constantinescu for her help in editing the manuscript.

\section{References}

1. World Health Organization (2020) WHO report on cancer: setting priorities, investing wisely and providing care for all. , Geneva.

2. Aust SD, Morehouse LA, Thomas CE (1985) Role of metals in oxygen radical reactions. J Free Radic Biol Med 1: 3-25.

3. Mello Filho AC, Meneghini R (1984) In vivo formation of single-strand breaks in DNA by hydrogen peroxide is mediated by the Haber-Weiss reaction. Biochim Biophys Acta 781: 56-63. 
4. Ionescu JG, Novotny J, Stejskal V, Laetsch A, Blaurock-Busch E, et al. (2006) Increased levels of transition metals in breast cancer tissue. Neuro Endocrinol Lett 27 Suppl 1: 36-39.

5. Ionescu J, Schulte-Uebbing C, Jennrich P (2018) Metabolic hallmarks of tumor cells as target for complementary therapies. Dtsch Zeitschrift fur Onkol 50: 108-119.

6. Millos J, Costas-Rodríguez M, Lavilla I, Bendicho C (2008) Multielementa determination in breast cancerous and non-cancerous biopsies by inductively coupled plasma-mass spectrometry following small volume microwave-assisted digestion. Anal Chim Acta 622: 77-84.

7. Ebrahim AM, Eltayeb MAH, Shaat MK, Mohmed NMA, Eltayeb EA, et al. (2007) Study of selected trace elements in cancerous and non-cancerous human breast tissues from Sudanese subjects using instrumental neutron activation analysis. Sci Total Environ 383: 52-58.

8. Millos J, Costas-Rodríguez M, Lavilla I, Bendicho C (2009) Multiple small volume microwave-assisted digestions using conventional equipment for multielemental analysis of human breast biopsies by inductively coupled plasma optical emission spectrometry. Talanta 77: 1490-1496.

9. Ng KH, Bradley DA, Looi LM (1997) Elevated trace element concentrations in malignant breast tissues. Br J Radiol 70: 375-382.

10. Ionescu JG (2007) Heavy Metal Accumulation in Malignant Tumours as Basis for a New Integrative Therapy Model. In Klatz R, Goldman R (eds.), Anti-Aging Therapeutics 9: 189-201.

11. Larrick JW, Cresswell P (1979) Modulation of cell surface iron transferrin receptors by cellular density and state of activation. J Supramol Struct 11: 579-586.

12. Schulte-Uebbing C, Jennrich P, Gerhard I, Zahn V, Craiut ID, et al. (2015) Prävention des Mammakarzinoms - endokrinologische und toxikologische Aspekte. Prävention und Rehabil 27: 26-37.

13. Elliott RL, Elliott MC, Wang F, Head JF (1993) Breast carcinoma and the role of iron metabolism. A cytochemical, tissue culture, and ultrastructural study. Ann N Y Acad Sci 698: 159-166.

14. Kovar J, Stunz LL, Stewart BC, Kriegerbeckova K, Ashman RF, et al. (1997) Direct evidence that iron deprivation induces apoptosis in murine lymphoma $38 \mathrm{C} 13$. Pathobiology 65: 61-68.

15. Kagara N, Tanaka N, Noguchi S, Hirano T (2007) Zinc and its transporter ZIP10 are involved in invasive behavior of breast cancer cells. Cancer Sci 98: 692-697.

16. Taylor KM, Morgan HE, Smart K, Zahari NM, Pumford S, et al. (2007) The emerging role of the LIV-1 subfamily of zinc transporters in breast cancer. Mol Med 13: 396-406.

17. Li M, Zhang Y, Liu Z, Bharadwaj U, Wang H, et al. (2007) Aberrant expression of zinc transporter ZIP4 (SLC39A4) significantly contributes to human pancreatic cancer pathogenesis and progression. Proc Natl Acad Sci U S A 104: 18636-18641.

18. Valko M, Izakovic M, Mazur M, Rhodes CJ, Telser J, et al. (2004) Role of oxygen radicals in DNA damage and cancer incidence. Mol Cell Biochem 266: 37-56.

19. Fukunari H, Iwama T, Sugihara K, Miyaki M (2003) Intratumoral heterogeneity of genetic changes in primary colorectal carcinomas with metastasis. Surg Today 33: 408413 .

20. Dexter DL, Leith JT (1986) Tumor heterogeneity and drug resistance. J Clin Oncol 4: 244-257.

21. Kemp JD, Smith KM, Kanner LJ, Gomez F, Thorson JA, et al. (1990) Synergistic inhibition of lymphoid tumor growth in vitro by combined treatment with the iron chelator deferoxamine and an immunoglobulin $\mathrm{G}$ monoclonal antibody against the transferrin receptor. Blood 76: 991-995.

22. Richardson DR (1997) Potential of iron chelators as effective antiproliferative agents. Can J Physiol Pharmacol 75: 1164-1180.

23. Buss JL, Torti FM, Torti S V (2003) The role of iron chelation in cancer therapy. Curr Med Chem 10: 1021-1034.

24. Donfrancesco A, Deb G, Dominici C, Angioni A, Caniglia M, et al. (1992) Deferoxamine, cyclophosphamide, etoposide, carboplatin, and thiotepa (D-CECaT) a new cytoreductive chelation-chemotherapy regimen in patients with advanced neuroblastoma. Am J Clin Oncol 15: 319-322.

25. Donfrancesco A, De Bernardi B, Carli M, Mancini A, Nigro M, et al. (1995) Deferoxamine followed by cyclophosphamide, etoposide, carboplatin, thiotepa, induction regimen in advanced neuroblastoma: preliminary results. Italian Neuroblastoma Cooperative Group. Eur J Cancer 31A: 612-615.
26. Beyersmann D (2002) Effects of carcinogenic metals on gene expression. Toxicol Lett 127: $63-68$.

27. Hartwig A (2000) Recent advances in metal carcinogenicity. Pure Appl Chem 72: 10071014.

28. Ohmori T, Okada K, Tabei R, Shibata T (1994) Effects on tumor induction, growth, metastasis and histology of concurrent administration of putrescine and its metabolizing inhibitor alpha-difluoromethylornithine in nickel tumorigenesis in soft tissue. Carcinogenesis 15: 647-652.

29. Yaman M, Atici D, Bakirdere S, Akdeniz I (2005) Comparison of trace metal concentrations in malign and benign human prostate. J Med Chem 48: 630-634.

30. Singh J, Carlisle DL, Pritchard DE, Patierno SR (1998) Chromium-induced genotoxicity and apoptosis: relationship to chromium carcinogenesis (review) Oncol Rep 5: 1307-1318.

31. Waalkes MP, Coogan TP, Barter RA (1992) Toxicological principles of metal carcinogenesis with special emphasis on cadmium. Crit Rev Toxicol 22: 175-201.

32. Byrne C, Divekar SD, Storchan GB, Parodi DA, Martin MB, et al. (2013) Metals and breast cancer. J Mammary Gland Biol Neoplasia 18: 63-73.

33. Martin MB, Reiter R, Pham T, Avellanet YR, Camara J, et al. (2003) Estrogen-Like Activity of Metals in Mcf-7 Breast Cancer Cells. Endocrinology 144: 2425-2436.

34. Akesson A, Julin B, Wolk A (2008) Long-term dietary cadmium intake and postmenopausal endometrial cancer incidence: a population-based prospective cohort study. Cancer Res 68: 6435-6441.

35. Jennrich P, Schulte-Uebbing C (2016) Einfluss toxischer Metalle auf die Krebsentstehung. Dtsch Zeitschrift für Onkol 48: 14-24.

36. McQuitty JT, DeWys WD, Monaco L, Strain WH, Rob CG, et al. (1970) Inhibition of tumor growth by dietary zinc deficiency. Cancer Res 30: 1387-1390.

37. Mills BJ, Broghamer WL, Higgins PJ, Lindeman RD (1984) Inhibition of tumor growth by zinc depletion of rats. $J$ Nutr 114: 746-752.

38. Takeda A, Goto K, Okada S (1997) Zinc depletion suppresses tumor growth in mice. Biol Trace Elem Res 59: 23-29.

39. Darbre PD (2005) Aluminium, antiperspirants and breast cancer. J Inorg Biochem 99 1912-1919

40. Lemire J, Mailloux R, Puiseux-Dao S, Appanna VD (2009) Aluminum-induced defective mitochondrial metabolism perturbs cytoskeletal dynamics in human astrocytoma cells. J Neurosci Res 87: 1474-1483.

41. Jennrich P, Schulte-Uebbing C (2015) Lost Aluminium Brustkrebs aus? Dtsch Zeitschrift für Onkol 47: 4-9.

42. Schulte-Uebbing C, Jennrich P, Gerhard I, Zahn V, Blaurock-Bush E, et al. (2015) Toxikologische, endokrinologische und immunologische Effekte Endokriner Disruptoren (ED) und dadurch verbundene Risiken für hormonabhängige Tumoren am Beispiel des Mamma- Karzinoms. Umwelt-Medizin-Gesellschaft 28: 37-45.

43. Ionescu J (2015) Die klinisch-therapeutische Relevanz der Redox-, pH- und Glukoseabbau-Verschiebungen im Tumorgewebe. Umwelt-Medizin-Gesellschaft 28: 86-92.

44. Shapiro HM (1972) Redox balance in the body: an approach to quantitation. J Surg Res 13: 138-152.

45. van Rossum JP, Schamhart DH (1991) Oxidation-reduction (redox) potentiometry in blood in geriatric conditions: a pilot study. Exp Gerontol 26: 37-43.

46. Schafer FQ, Buettner GR (2001) Redox environment of the cell as viewed through the redox state of the glutathione disulfide/glutathione couple. Free Radic Biol Med 30: $1191-1212$

47. Yeh C-C, Hou M-F, Wu S-H, Tsai S-M, Lin S-K, et al. (2006) A study of glutathione status in the blood and tissues of patients with breast cancer. Cell Biochem Funct 24: 555-559.

48. Lusini L, Tripodi SA, Rossi R, Giannerini F, Giustarini D, et al. (2001) Altered glutathione anti-oxidant metabolism during tumor progression in human renal-cell carcinoma. Int J Cancer 91: 55-59.

49. DeBerardinis RJ, Mancuso A, Daikhin E, Nissim I, Yudkoff M, et al. (2007) Beyond aerobic glycolysis: transformed cells can engage in glutamine metabolism that exceeds the requirement for protein and nucleotide synthesis. Proc Natl Acad Sci U S A 104 19345-19350. 
50. Kroemer G, Pouyssegur J (2008) Tumor Cell Metabolism: Cancer's Achilles' Heel. Cancer Cell 13: 472-482.

51. Pouysségur J, Dayan F, Mazure NM (2006) Hypoxia signalling in cancer and approaches to enforce tumour regression. Nature 441: 437-443.

52. Güttes S, Failing K, Neumann K, Kleinstein J, Georgii S, et al. (1998) Chlororganic pesticides and polychlorinated biphenyls in breast tissue of women with benign and malignant breast disease. Arch Environ Contam Toxicol 35: 140-147.

53. Aronson KJ, Miller AB, Woolcott CG, Sterns EE, McCready DR, et al. (2000) Breast adipose tissue concentrations of polychlorinated biphenyls and other organochlorines and breast cancer risk. Cancer Epidemiol biomarkers Prev 9: 55-63.

54. Eldakroory SA, Morsi D El, Abdel-Rahman RH, Roshdy S, Gouida MS, et al. (2017) Correlation between toxic organochlorine pesticides and breast cancer. Hum Exp Toxicol 36: 1326-1334.

55. Strumylaite L, Bogusevicius A, Abdrachmanovas O, Baranauskiene D, Kregzdyte R, et al. (2011) Cadmium concentration in biological media of breast cancer patients. Breast Cancer Res Treat 125: 511-517.

56. Perera FP, Mooney LA, Stampfer M, Phillips DH, Bell DA, et al. (2002) Associations between carcinogen-DNA damage, glutathione S-transferase genotypes, and risk of lung cancer in the prospective Physicians' Health Cohort Study. Carcinogenesis 23: 1641-1646.

57. Rundle A, Tang D, Zhou J, Cho S, Perera F (2000) The association between glutathione S-transferase M1 genotype and polycyclic aromatic hydrocarbon-DNA adducts in breast tissue. Cancer Epidemiol Biomarkers Prev 9: 1079-1085.

58. Sanchez M, Torres JV, Tormos C, Iradi A, Muñiz P, et al. (2006) Impairment of antioxidant enzymes, lipid peroxidation and 8-oxo-2'-deoxyguanosine in advanced epithelial ovarian carcinoma of a Spanish community. Cancer Lett 233: 28-35.

59. Searles Nielsen S, McKean-Cowdin R, Farin FM, Holly EA, Preston-Martin S, et al. (2010) Childhood brain tumors, residential insecticide exposure, and pesticide metabolism genes. Environ Health Perspect 118: 144-149.

60. Karami S, Boffetta P, Rothman N, Hung RJ, Stewart T, et al. (2008) Renal cell carcinoma, occupational pesticide exposure and modification by glutathione S-transferase polymorphisms. Carcinogenesis 29: 1567-1571.

61. Buzio L, De Palma G, Mozzoni P, Tondel M, Buzio C, et al. (2003) Glutathione S-transferases M1-1 and T1-1 as risk modifiers for renal cell cancer associated with occupational exposure to chemicals. Occup Environ Med 60: 789-793.

62. Russo A, Carmichael J, Friedman N, DeGraff W, Tochner Z, et al. (1986) The roles of intracellular glutathione in antineoplastic chemotherapy. Int J Radiat Oncol Biol Phys 12: $1347-1354$.

63. Godwin AK, Meister A, O’Dwyer PJ, Huang CS, Hamilton TC, et al. (1992) High resistance to cisplatin in human ovarian cancer cell lines is associated with marked increase of glutathione synthesis. Proc Natl Acad Sci U S A 89: 3070-3074.

64. Backos DS, Franklin CC, Reigan P (2012) The role of glutathione in brain tumor drug resistance. Biochem Pharmacol 83: 1005-1012.

65. Wang T, Marquardt C, Foker J (1976) Aerobic glycolysis during lymphocyte proliferation. Nature 261: 702-705.

66. Brand KA, Hermfisse U (1997) Aerobic glycolysis by proliferating cells: a protective strategy against reactive oxygen species. FASEB $J$ 11: 388-395.

67. Bauer DE, Harris MH, Plas DR, Lum JJ, Hammerman PS, et al. (2004) Cytokine stimulation of aerobic glycolysis in hematopoietic cells exceeds proliferative demand. FASEB J 18: 1303-1305.

68. Reshkin SJ, Bellizzi A, Caldeira S, Albarani V, Malanchi I, et al. (2000) $\mathrm{Na}+/ \mathrm{H}+$ exchanger-dependent intracellular alkalinization is an early event in malignant transformation and plays an essential role in the development of subsequent transformation-associated phenotypes. FASEB J 14: 2185-2197.

69. Cardone RA, Casavola V, Reshkin SJ (2005) The role of disturbed $\mathrm{pH}$ dynamics and the $\mathrm{Na}+/ \mathrm{H}+$ exchanger in metastasis. Nat Rev Cancer 5: 786-795.

70. Gillies RJ, Raghunand N, Karczmar GS, Bhujwalla ZM (2002) MRI of the tumor microenvironment. J Magn Reson Imaging 16: 430-450.

71. Warburg O (1956) On the Origin of Cancer Cells. Science (80- ) 123: 309-314.

72. Gatenby RA, Gillies RJ (2004) Why do cancers have high aerobic glycolysis? Nat Rev Cancer 4: 891-899.
73. Pedersen PL (2007) Warburg, me and Hexokinase 2: Multiple discoveries of key molecular events underlying one of cancers' most common phenotypes, the 'Warburg Effect', i.e., elevated glycolysis in the presence of oxygen. J Bioenerg Biomembr 39: 211-222.

74. Fang JS, Gillies RD, Gatenby RA (2008) Adaptation to hypoxia and acidosis in carcinogenesis and tumor progression. Semin Cancer Biol 18: 330-337.

75. Sonveaux P, Végran F, Schroeder T, Wergin MC, Verrax J, et al. (2008) Targeting lactate-fueled respiration selectively kills hypoxic tumor cells in mice. J Clin Invest 118: 3930-3942.

76. Pérez-Sayáns M, Somoza-Martín JM, Barros-Angueira F, Rey JMG, García-García A, et al. (2009) V-ATPase inhibitors and implication in cancer treatment. Cancer Treat Rev 35: 707-713.

77. Fais S (2010) Proton pump inhibitor-induced tumour cell death by inhibition of a detoxification mechanism: Symposium. J Intern Med 267: 515-525.

78. Spugnini EP, Citro G, Fais S (2010) Proton pump inhibitors as anti vacuolar-ATPases drugs: a novel anticancer strategy. J Exp Clin Cancer Res 29: 44.

79. Neri D, Supuran CT (2011) Interfering with $\mathrm{pH}$ regulation in tumours as a therapeutic strategy. Nat Rev Drug Discov 10: 767-777.

80. Supuran CT (2008) Carbonic anhydrases: novel therapeutic applications for inhibitors and activators. Nat Rev Drug Discov 7: 168-181.

81. Supuran CT (2010) Carbonic anhydrase inhibitors. Bioorg Med Chem Lett 20: $3467-$ 3474.

82. Švastová E, Hulíková A, Rafajová M, Zat'Ovičová M, Gibadulinová A, et al. (2004) Hypoxia activates the capacity of tumor-associated carbonic anhydrase IX to acidify extracellular pH. FEBS Lett 577: 439-445.

83. Hilvo M, Baranauskiene L, Salzano AM, Scaloni A, Matulis D, et al. (2008) Biochemical characterization of CA IX, one of the most active carbonic anhydrase isozymes. J Biol Chem 283: 27799-27809.

84. Sowah D, Casey JR (2011) An intramolecular transport metabolon: fusion of carbonic anhydrase II to the $\mathrm{COOH}$ terminus of the $\mathrm{Cl}(-) / \mathrm{HCO}(3)(-)$ exchanger, $\mathrm{AE} 1 . \mathrm{Am} J$ Physiol Cell Physiol 301: C336-C346.

85. Morgan PE, Pastoreková S, Stuart-Tilley AK, Alper SL, Casey JR, et al. (2007) Interactions of transmembrane carbonic anhydrase, CAIX, with bicarbonate transporters. Am J Physiol Cell Physiol 293: C738-C748.

86. Harguindey S, Orive G, Pedraz JL, Paradiso A, Reshkin SJ, et al. (2005) The role of pH dynamics and the $\mathrm{Na}+/ \mathrm{H}+$ antiporter in the etiopathogenesis and treatment of cancer Two faces of the same coin - One single nature. Biochim Biophys Acta-Rev Cancer 1756: $1-24$.

87. Husain Z, Huang Y, Seth P, Sukhatme VP (2013) Tumor-derived lactate modifies antitumor immune response: effect on myeloid-derived suppressor cells and NK cells. J Immunol 191: 1486-1495.

88. Fischer K, Hoffmann P, Voelkl S, Meidenbauer N, Ammer J, et al. (2007) Inhibitory effect of tumor cell-derived lactic acid on human T cells. Blood 109: 3812-3819.

89. Lu H, Forbes RA, Verma A (2002) Hypoxia-inducible factor 1 activation by aerobic glycolysis implicates the Warburg effect in carcinogenesis. J Biol Chem 277: 2311123115 .

90. Lu H, Dalgard CL, Mohyeldin A, McFate T, Tait AS, et al. (2005) Reversible inactivation of HIF-1 prolyl hydroxylases allows cell metabolism to control basal HIF1. J Biol Chem 280: 41928-41939.

91. Papandreou I, Cairns RA, Fontana L, Lim AL, Denko NC, et 1. (2006) HIF-1 mediates adaptation to hypoxia by actively downregulating mitochondrial oxygen consumption. Cell Metab 3: 187-197.

92. Yeung SJ, Pan J, Lee M-H (2008) Roles of p53, MYC and HIF-1 in regulating glycolysis - the seventh hallmark of cancer. Cell Mol Life Sci 65: 3981-3999.

93. Ionescu J, Poljsak B (2010) Metal Ions Mediated Pro-Oxidative Reactions with Vitamin C: Possible Implications for Treatment of Different Malignancies. Int J Cancer Prev 3: 149-174.

94. Baader SL, Bruchelt G, Carmine TC, Lode HN, Rieth AG, et al. (1994) Ascorbic-acidmediated iron release from cellular ferritin and its relation to the formation of DNA strand breaks in neuroblastoma cells. J Cancer Res Clin Oncol 120: 415-421.

95. Ionescu J (2005) New evidence based therapies for cancer. In: Proceedings of the 17th Int Symposium on Integrative Medicine, Tenerife, Spain, pp: 1-21. 
96. Lode HN, Bruchelt G, Zinsser D, Baader SL, Rieth AG, et al. (1994) Ascorbic acid induces lipid peroxidation on neuroectodermal SK-N-LO cells with high endogenous ferritin content and loaded with MAb-ferritin immunoconjugates. Anticancer Res 14: 1903-1906.

97. Babich H, Schuck AG, Weisburg JH, Zuckerbraun HL (2011) Research strategies in the study of the pro-oxidant nature of polyphenol nutraceuticals. J Toxicol.

98. Okada S (1996) Iron-induced tissue damage and cancer: the role of reactive oxygen species-free radicals. Pathol Int 46: 311-332.

99. Ionescu JG (2010) Free radical monitoring in human blood following therapy interventions with drugs and natural compounds. Médecine \& Longévité 2: 211-220.

100. Ahmad A, Syed FA, Singh S, Hadi SM (2005) Prooxidant activity of resveratrol in the presence of copper ions: Mutagenicity in plasmid DNA. Toxicol Lett 159: 1-12.

101. Wondrak GT (2009) Redox-directed cancer therapeutics: molecular mechanisms and opportunities. Antioxid Redox Signal 11: 3013-3069.

102. Ross D, Traver RD, Siegel D, Kuehl BL, Misra V, et al. (1996) A polymorphism in $\mathrm{NAD}(\mathrm{P}) \mathrm{H}$ :quinone oxidoreductase (NQO1): relationship of a homozygous mutation at position 609 of the NQO1 cDNA to NQO1 activity. Br J Cancer 74: 995-996.

103. Phillips RM, Naylor MA, Jaffar M, Doughty SW, Everett SA, et al. (1999) Bioreductive activation of a series of indolequinones by human DT-diaphorase: structure-activity relationships. J Med Chem 42: 4071-4080.

104. Lin YG, Kunnumakkara AB, Nair A, Merritt WM, Han LY, et al. (2007) Curcumin inhibits tumor growth and angiogenesis in ovarian carcinoma by targeting the nuclear factor-kappaB pathway. Clin cancer Res 13: 3423-3430.

105. Duarte VM, Han E, Veena MS, Salvado A, Suh JD, et al. (2010) Curcumin enhances the effect of cisplatin in suppression of head and neck squamous cell carcinoma via inhibition of IKK $\beta$ protein of the NFкB pathway. Mol Cancer Ther 9: 2665-2675.

106. Lee C, Longo VD (2011) Fasting vs dietary restriction in cellular protection and cancer treatment: from model organisms to patients. Oncogene 30: 3305-3316.

107. Bianchi G, Martella R, Ravera S, Marini C, Capitanio S, et al. (2015) Fasting induces anti-Warburg effect that increases respiration but reduces ATP-synthesis to promote apoptosis in colon cancer models. Oncotarget 6: 11806-11819.

108. Zhou W, Mukherjee P, Kiebish MA, Markis WT, Mantis JG, et al. (2007) The calorically restricted ketogenic diet, an effective alternative therapy for malignant brain cancer. Nutr Metab (Lond) 4: 5 .

109. Abdelwahab MG, Fenton KE, Preul MC, Rho JM, Lynch A, et al. (2012) The ketogenic diet is an effective adjuvant to radiation therapy for the treatment of malignant glioma. PLoS One 7:

110. Reinwald H (2014) Ketogenic diet with MAP in cancer: new chances in tumor cachexia. World Congr Biol cancer Treat Frankfurt/Main.

111. Siegmund-Schultze N (2009) Sport ist so wichtig wie ein Krebsmedikament. Dtsch Artzeblatt 106: 444-447.

112. Fine EJ, Segal-Isaacson CJ, Feinman RD, Herszkopf S, Romano MC, et al. (2012) Targeting insulin inhibition as a metabolic therapy in advanced cancer: a pilot safety and feasibility dietary trial in 10 patients. Nutrition $28: 1028-1035$.

113. Robey IF, Baggett BK, Kirkpatrick ND, Roe DJ, Dosescu J, et al. (2009) Bicarbonate increases tumor $\mathrm{pH}$ and inhibits spontaneous metastases. Cancer Res 69: 2260-2268.

114. Fais S, Venturi G, Gatenby B (2014) Microenvironmental acidosis in carcinogenesis and metastases: new strategies in prevention and therapy. Cancer Metastasis Rev 33: 1095-1108.
115. Raghunand N, He X, van Sluis R, Mahoney B, Baggett B, et al. (1999) Enhancement of chemotherapy by manipulation of tumour $\mathrm{pH}$. Br J Cancer 80: 1005-1011.

116. Low PS, Kularatne SA (2009) Folate-targeted therapeutic and imaging agents for cancer. Curr Opin Chem Biol 13: 256-262.

117. De Milito A, Iessi E, Logozzi M, Lozupone F, Spada M, et al. (2007) Proton pump inhibitors induce apoptosis of human B-cell tumors through a caspase-independent mechanism involving reactive oxygen species. Cancer Res 67: 5408-5417.

118. Cooper BT, Chapman W, Neumann CS, Gearty JC (2006) Continuous treatment of Barrett's oesophagus patients with proton pump inhibitors up to 13 years: observations on regression and cancer incidence. Aliment Pharmacol Ther 23: 727-733.

119. Ohta T, Arakawa H, Futagami F, Fushida S, Kitagawa H, et al. (1998) Bafilomycin A1 induces apoptosis in the human pancreatic cancer cell line Capan-1. J Pathol 185: 324-330.

120. Wang B-Y, Zhang J, Wang J-L, Sun S, Wang Z-H, et al. (2015) Intermittent high dose proton pump inhibitor enhances the antitumor effects of chemotherapy in metastatic breast cancer. J Exp Clin cancer Res 34: 85.

121. Rich IN, Worthington-White D, Garden OA, Musk P (2000) Apoptosis of leukemic cells accompanies reduction in intracellular $\mathrm{pH}$ after targeted inhibition of the $\mathrm{Na}(+) / \mathrm{H}(+)$ exchanger. Blood 95: 1427-1434.

122. Harley W, Floyd C, Dunn T, Zhang XD, Chen TY, et al. (2010) Dual inhibition of sodium-mediated proton and calcium efflux triggers non-apoptotic cell death in malignant gliomas. Brain Res 1363: 159-169.

123. Masereel B, Pochet L, Laeckmann D (2003) An overview of inhibitors of $\mathrm{Na}+\mathrm{H}+$ exchanger. Eur J Med Chem 38: 547-554.

124. Ahlskog JKJ, Dumelin CE, Trüssel S, Mårlind J, Neri D, et al. (2009) In vivo targeting of tumor-associated carbonic anhydrases using acetazolamide derivatives. Bioorganic Med Chem Lett 19: 4851-4856.

125. Maresca A, Temperini C, Vu H, Pham NB, Poulsen SA, et al. (2009) Non-zinc mediated inhibition of carbonic anhydrases: Coumarins are a new class of suicide inhibitors. J Am Chem Soc 131: 3057-3062.

126. Maresca A, Temperini C, Pochet L, Masereel B, Scozzafava A, et al. (2010) Deciphering the mechanism of carbonic anhydrase inhibition with coumarins and thiocoumarins. J Med Chem 53: 335-344.

127. Ionescu JG (2019) Inhibition of Cancer Spreading by Modulation of Tumor Redoxand $\mathrm{pH}-$ Homeostasys. Proceedings of the International Congress of Cancer and Clinical Oncology 5-7, 71: Singapore

128. Schilling F (2014) Metabolic tumor typing - a crucial analysis for therapy strategy World Congr Biol cancer Treat Frankfurt/Main.

129. Michelakis ED, Sutendra G, Dromparis P, Webster L, Haromy A, et al. (2010) Metabolic modulation of glioblastoma with dichloroacetate. Sci Transl Med 2: 31-34.

130. Ko YH, Verhoeven HA, Lee MJ, Corbin DJ, Vogl TJ, et al. (2012) A translational study 'case report' on the small molecule 'energy blocker' 3-bromopyruvate (3BP) as a potent anticancer agent: from bench side to bedside. J Bioenerg Biomembr 44 : 163-170.

131. Awad AB, Bradford PG (2005) Nutrition and cancer prevention. CRC Press.

132. Gerlinger M, Rowan AJ, Horswell S, Math M, Larkin J, et al. (2012) Intratumor heterogeneity and branched evolution revealed by multiregion sequencing. $N$ Engl JMed 366: 883-892.

Copyright: (C2020 Ionescu J. This is an open-access article distributed under the terms of the Creative Commons Attribution License, which permits unrestricted use, distribution, and reproduction in any medium, provided the original author and source are credited. 